ISSN 1392-3196 / e-ISSN 2335-8947

Zemdirbyste-Agriculture, vol. 102, No. 2 (2015), p. 217-222

DOI $10.13080 /$ z-a.2015.102.028

\title{
Correlations between the germination capacity and selected physical properties of cultivated radish seeds
}

\author{
Zdzislaw KALINIEWICZ, Krzysztof JADWISIEŃCZAK, Piotr MARKOWSKI, \\ Dariusz CHOSZCZ, Ewelina KOLANKOWSKA \\ University of Warmia and Mazury \\ Oczapowskiego 11/B112, 10-719 Olsztyn, Poland \\ E-mail: zdzislaw.kaliniewicz@uwm.edu.pl
}

\begin{abstract}
Relationships between the physical properties of seed and their germination capacity and energy is an important consideration for separating seeds of the highest or lowest quality. The objective of this study was to determine the correlations between the selected aerodynamic, geometric, frictional and mass parameters of cultivated radish (Raphanus sativus L.) seeds and their germination capacity for the purpose of improving seed quality. The parameters were determined for graded and discarded radish seeds and impurities were separated by a gravity separator. A germination test was performed, its results were verified every 12 hours, and the germination rate index was determined. A statistical analysis revealed that germinated and non-germinated seeds from the graded fraction did not differ significantly. In the discarded fraction, germinated seeds were characterized by higher terminal velocity (by approx. 10\%), thickness (by approx. 9\%) and mass (by approx. 26\%) in comparison with non-germinated seeds. Significant positive correlations were noted between the germination time $v s$ terminal velocity and mass of discarded seeds. Thus, the separation of radish seeds should take place in two stages using a gravity separator and a pneumatic separator. A vertical stream of air with the speed of approx. $8 \mathrm{~m} \mathrm{~s}^{-1}$ allows recovery of around $37 \%$ of discarded seeds that contain approx. $86 \%$ of healthy germs. The resulting seed mixture is characterized by greater germination energy and capacity than the seed fraction graded on a gravity separator only.
\end{abstract}

Key words: germination, physical properties, radish seeds.

\section{Introduction}

The cultivated radish is a popular root vegetable, appreciated for its relatively low cultivation requirements and high biological value resulting from the presence of sugars, vitamins and mineral compounds (Pérez Gutiérrez, Perez, 2004; Kang, Wan, 2005; Blažević, Mastelić, 2009). Radishes have a short growing season, and they can be grown as a forecrop and an aftercrop, both in the field and under cover. In Poland, separate crop production records for cultivated radish are not kept. The record keeping system contains combined data on the total cultivated area and harvestable yields of vegetable species such as radish, parsley, leek, celery, lettuce, rhubarb, asparagus, dill and others. Radishes play an important role in Polish cuisine, particularly in spring and summer. They are usually eaten raw in salads or on sandwiches, and added to eggs, cottage cheese and vegetable soups served cold.

The quality of crop seeds, including vegetable seeds, is determined by the genotype and habitat conditions which affect plants during growth and harvest (Nik et al., 2011). Environmental conditions include, among others, the availability of water, the chemical composition of soil, ambient temperature, plant density, fertilization, light access and seed distribution on a plant (Martinez-Villaluenga et al., 2010). Germination capacity can be improved with the use of chemical, physical and physiological methods (Andreoli, Khan, 2000) such as seed dressing and encapsulation (Domoradzki, Korpal, 2009), seed conditioning (Maroufi, Farahani, 2011), exposure to visible light with different wavelength and intensity (Muszyński, Gładyszewska, 2008) or stimulation with static or variable electromagnetic field (Lynikiene et al., 2006; Haq et al., 2012; Jamil et al., 2012; Krawiec et al., 2012). Laboratory and field experiments (Mut, Akay, 2010; Hojjat, 2011; Nik et al., 2011; Amin, Brinis, 2013) have revealed that germination energy and capacity are determined by seed size. Larger and heavier seeds germinate earlier, seedlings develop into larger plants and produce higher yield. Germination capacity seems to be most correlated with seed mass because plump seeds contain more nutrient resources which support seedling emergence.

Seeds are usually cleaned and graded using pneumatic and air-screen separators, which are characterized by high efficiency. If the results are not satisfactory, the separation process can be continued with the use of graders, triers and gravity separators. Relatively high efficiency of radish seed separation with gravity separators has been observed in the Torseed Seed Production and Nursery Center in Torun, Poland during long-term experiments. However, the fraction discarded in the production process has been found to contain a 
considerable number of radish seeds, characterized by high sowing value, which should not be removed.

There is a general scarcity of published data about the correlations between the physical properties of radish seeds and their germination energy and capacity. A better understanding of those parameters is required for seed cleaning and sorting processes and designing effective methods for separating seeds of the highest or lowest quality.

The objective of this study was to determine the correlations between the basic physical parameters of cultivated radish seeds and their germination capacity for the purpose of increasing the efficiency of seed separation processes.

\section{Materials and methods}

Cultivated radish seeds were collected before and during harvest, between September and October 2013. The experimental material comprised samples of cultivated radish (Raphanus sativus L.) seeds of the variety 'Krasa' produced in Gołębin $\left(52.53^{\circ} \mathrm{N}, 18.94^{\circ} \mathrm{E}\right)$, Poland. The seeds were delivered to the Torseed Seed Production and Nursery Center in Torun, Poland and were separated on the gravity separator KA-2200 ("Westrub", Sweden). The following parameters of the graded product (comprising $87 \%$ of the initial seed mixture by mass) were given by the manufacturer: purity $-98.2 \%$, relative moisture content $-7.6 \%$ and germination capacity $-61 \%$. The analyzed seeds did not conform to company standards based on ISTA (2014) guidelines which set the following quality requirements: purity - minimum $98 \%$, relative moisture content - up to $9 \%$ and germination capacity - minimum $70 \%$. Samples of approximately $1 \mathrm{~kg}$ each were collected from the graded product and the discarded fraction, and they were successively halved to produce at least 100 particles (seeds and impurities) per sample (Załęski, 1995). A total of 146 seeds were obtained from the graded product, and 193 particles were acquired from the discarded fraction (135 seeds and 58 impurities).

Laboratory tests were performed at the Laboratory of Agricultural Product Separation, Department of Heavy Duty Machines and Research Methodology, University of Warmia and Mazury in Olsztyn, Poland. Terminal velocity $(v)$ was determined in the pneumatic classifier Petkus K-293 (PETKUS Technolologie GmbH, Germany), seed dimensions were measured under the workshop microscope MWM 1275 (PZO, Poland): length $(L)$, width $(W)$ and a thickness $(T)$ gauge, the angle of sliding friction $(\gamma)$ was measured on a horizontal plane with an adjustable angle of inclination, and seed mass $(m)$ was determined on the laboratory scale WAA 100/C/2 ("Radwag", Poland). All measurements were performed according to the methods previously described by Kaliniewicz et al. (2011).

In the discarded fraction, the morphological index of seed separation on was determined based on the following formula:

$$
\delta=\left|\frac{x_{1}-x_{2}}{3\left(S D_{1}+S D_{2}\right)}\right|
$$

where subscripts 1 and 2 by the relevant symbols denote the mean value $(x)$ and standard deviation $(S D)$ of the analyzed physical parameters of whole radish seeds and impurities (including broken radish seeds).
The germination rate index $\left(W_{g}\right)$ was calculated for every radish seed:

$$
W_{g}=\frac{T_{o}+1-T_{n}}{T_{o}+1}
$$

where: $T_{n}$ is the time required for germination (day), $T_{o}$ - time of germination test (day).

During germination test, whole radish seeds were placed in a tank lined with moistened filter paper and covered with a glass lid. Evaporated water was supplemented daily with a sprinkler, and filter paper was kept moist throughout the experiment. The test was carried out at the temperature of approximately $+25^{\circ} \mathrm{C}$ under exposure to natural light. Germination progress was monitored daily between 8 and 9 a.m. Seeds that produced a sprout with a minimum length of $75 \%$ seed length were classified as germinated (Załęski, 1995). Observations were continued for 14 days. Germination energy $\left(V_{g}\right)$ and germination capacity $\left(C_{g}\right)$ were determined based on the ratio of the number of seeds that had germinated within 10 and 14 days to the number of seeds in the analyzed sample.

The results were processed with the use of STATISTICA PL, v. 10 application based on general statistical procedures, including the Student's $t$-test for independent samples, one-way ANOVA and correlation analysis. Statistical calculations were performed at the significance level of 0.05 .

\section{Results and discussion}

The physical parameters of graded and discarded cultivated radish seeds and discarded impurities are given in Table 1. The highest values of the coefficient of variation were noted for the mass of seeds and impurities, and the lowest - for the length of discarded seeds and impurities, and the terminal velocity of graded seeds. The analyzed physical parameters of cultivated radish seeds varied within the following ranges of values: terminal velocity - from 5.78 to $10.73 \mathrm{~m} \mathrm{~s}^{-1}$, thickness - from 0.99 to $2.62 \mathrm{~mm}$, width - from 1.39 to $3.36 \mathrm{~mm}$, length - from 1.94 to $4.24 \mathrm{~mm}$, angle of external friction - from $14^{\circ}$ to $57^{\circ}$, mass - from 3.3 to $20.6 \mathrm{mg}$. The analyzed seeds were characterized by average plumpness, and their average mass and dimensions were somewhat smaller than those determined by Çetin et al. (2010). The evaluated seeds were also characterized by higher average terminal velocity. Graded seeds differed from discarded seeds with respect to nearly all of the analyzed parameters. The above seed groups differed significantly only with regard to their angles of external friction. Impurities and whole discarded seeds differed in every analyzed trait. In comparison with impurities, discarded seeds were characterized by higher terminal velocity, thickness and mass, but lower average width, length and angle of external friction.

Despite the presence of statistically significant differences between the average values of physical parameters, the morphological index of seed separation assumed relatively low values in the mixture of discarded seeds and impurities (Fig. 1). The values less than unity imply that the components of the analyzed mixture cannot be effectively separated based on a single separation trait. It was assumed that selected fractions of whole seeds can be separated based on their terminal velocity and/or 
thickness. The validity of the above assumption should be preceded by an analysis of germination capacity and the determination of the presence of healthy germinating seeds in the discarded fraction.
Graded seeds were characterized by $V=$ $71.2 \%$ and $C=82.2 \%$, and discarded seeds - by ${ }^{g}=$ $63.0 \%$ and $C_{g}=69.6 \%$. The above results suggest that

Table 1. Statistical distribution of the physical parameters of the cultivated radish seed mixture

\begin{tabular}{|c|c|c|c|c|c|c|}
\hline \multirow{2}{*}{ Particle } & \multirow{2}{*}{$\begin{array}{l}\text { Physical } \\
\text { parameter }\end{array}$} & \multicolumn{3}{|c|}{ Value of trait } & \multirow{2}{*}{$\begin{array}{c}\text { Standard deviation } \\
\text { of trait }\end{array}$} & \multirow{2}{*}{$\begin{array}{c}\text { Coefficient of } \\
\text { trait variability } \\
\%\end{array}$} \\
\hline & & minimum & maximum & average & & \\
\hline \multirow{6}{*}{ Graded seeds } & $v\left(\mathrm{~m} \mathrm{~s}^{-1}\right)$ & 6.88 & 10.18 & $8.82 \mathrm{a}$ & 0.820 & 9.30 \\
\hline & $T(\mathrm{~mm})$ & 1.19 & 2.62 & $1.89 \mathrm{a}$ & 0.259 & 13.70 \\
\hline & $W(\mathrm{~mm})$ & 1.75 & 3.36 & $2.49 \mathrm{a}$ & 0.321 & 12.90 \\
\hline & $L(\mathrm{~mm})$ & 2.19 & 3.86 & $3.11 \mathrm{a}$ & 0.363 & 11.64 \\
\hline & $\gamma\left({ }^{\circ}\right)$ & 14 & 57 & $31.5 \mathrm{~b}$ & 6.850 & 21.77 \\
\hline & $m(\mathrm{mg})$ & 3.7 & 17.3 & $10.3 \mathrm{a}$ & 2.911 & 28.17 \\
\hline \multirow{6}{*}{ Discarded seeds } & $v\left(\mathrm{~m} \mathrm{~s}^{-1}\right)$ & 5.78 & 10.73 & $7.82 \mathrm{~b}$ & 1.054 & 13.48 \\
\hline & $T(\mathrm{~mm})$ & 0.99 & 2.33 & $1.61 \mathrm{~b}$ & 0.312 & 19.37 \\
\hline & $W(\mathrm{~mm})$ & 1.39 & 3.32 & $2.29 \mathrm{~b}$ & 0.365 & 15.89 \\
\hline & $L(\mathrm{~mm})$ & 1.94 & 4.24 & $2.86 \mathrm{~b}$ & 0.368 & 12.87 \\
\hline & $\gamma\left({ }^{\circ}\right)$ & 16 & 54 & $34.4 \mathrm{~b}$ & 8.236 & 24.63 \\
\hline & $m(\mathrm{mg})$ & 3.3 & 20.6 & $7.3 \mathrm{~b}$ & 2.964 & 40.83 \\
\hline \multirow{6}{*}{$\begin{array}{l}\text { Discarded } \\
\text { impurities }\end{array}$} & $v\left(\mathrm{~m} \mathrm{~s}^{-1}\right)$ & 4.13 & 7.98 & $6.57 \mathrm{c}$ & 1.010 & 15.37 \\
\hline & $T(\mathrm{~mm})$ & 0.17 & 1.94 & $1.36 \mathrm{c}$ & 0.307 & 22.68 \\
\hline & $W(\mathrm{~mm})$ & 1.39 & 3.02 & $2.36 \mathrm{a}$ & 0.343 & 14.50 \\
\hline & $L(\mathrm{~mm})$ & 1.90 & 4.22 & $3.07 \mathrm{a}$ & 0.430 & 14.02 \\
\hline & $\gamma\left({ }^{\circ}\right)$ & 24 & 58 & $37.5 \mathrm{a}$ & 8.185 & 21.85 \\
\hline & $m(\mathrm{mg})$ & 0.6 & 12.9 & $6.0 \mathrm{c}$ & 2.468 & 40.83 \\
\hline
\end{tabular}

Note. $v$-terminal velocity, $T$ - thickness, $W$ - width, $L$ - length, $\gamma$ - angle of sliding friction, $m$ - mass; a, b, c-identical superscripts denote no significant differences.

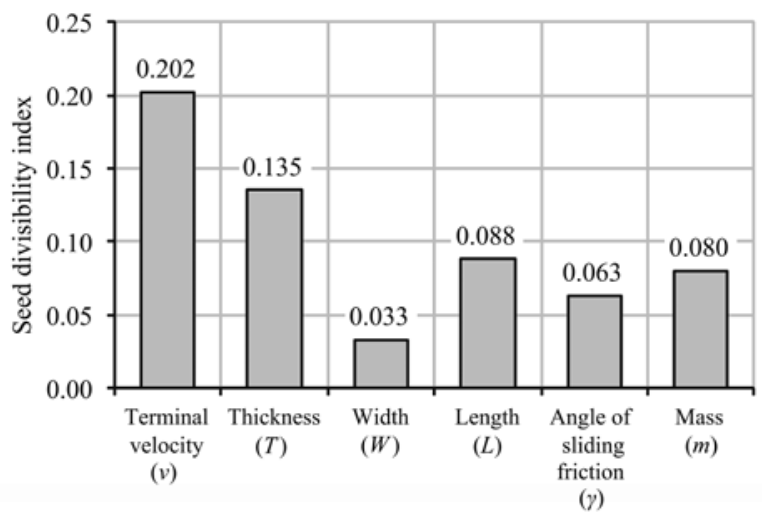

Figure 1. Morphological index of seed separation based on the physical properties of whole discarded cultivated radish seeds and impurities

germination capacity values given by the manufacturer were underestimated and that the analyzed material met standard requirements. Figure 2 shows the percentage structure of radish seeds that germinated on successive days of the germination period. Peak germination values were noted on days 2 and 3, when healthy sprouts were observed in more than $50 \%$ of both graded and discarded seeds. Since day 5 , the seeds that germinated daily did not exceed $4 \%$ of all seeds. Germination ceased on day 13 in the graded fraction and on day 11 in the discarded fraction. Since the percentage of non-germinated seeds was over three-fold higher in the discarded fraction than in the graded fraction, cultivated radish seeds should be separated with the use of a gravity separator, as it is done in the Torseed Seed Production and Nursery Center in Toruń, Poland.

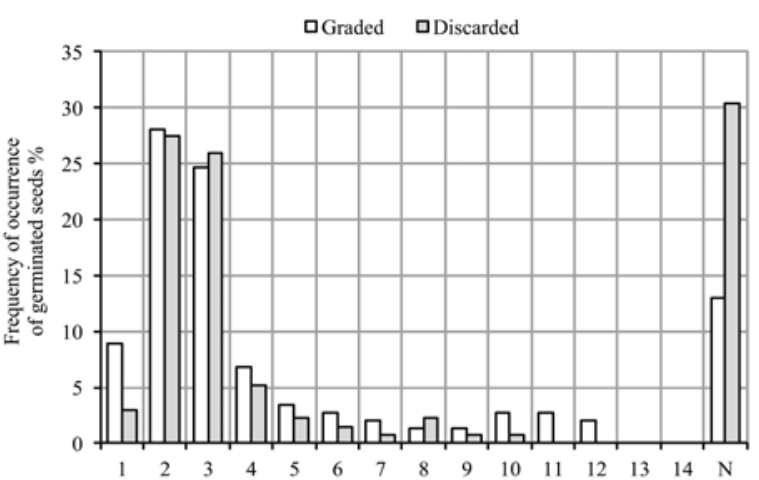

$\mathrm{N}$ - non-germinating seeds

Figure 2. Percentage structure of germinating cultivated radish seeds

The results of the Student's $t$-test for independent samples (Fig. 3) indicate that germinated and nongerminated seeds from the graded fraction did not differ significantly with regard to the analyzed physical properties. Germinated and non-germinated seeds from the discarded fraction differed in their terminal velocity, thickness and mass. The above parameters and indicators can be used as separation traits to recover healthy germinated seeds from the discarded fraction.

The results of a linear correlation analysis of selected physical attributes of graded and discarded cultivated radish seeds are presented in Table 2. The critical value of the correlation coefficient was exceeded for the majority of analyzed traits, which implies that the physical parameters of cultivated radish seeds are correlated. Therefore, in the sorting process different 

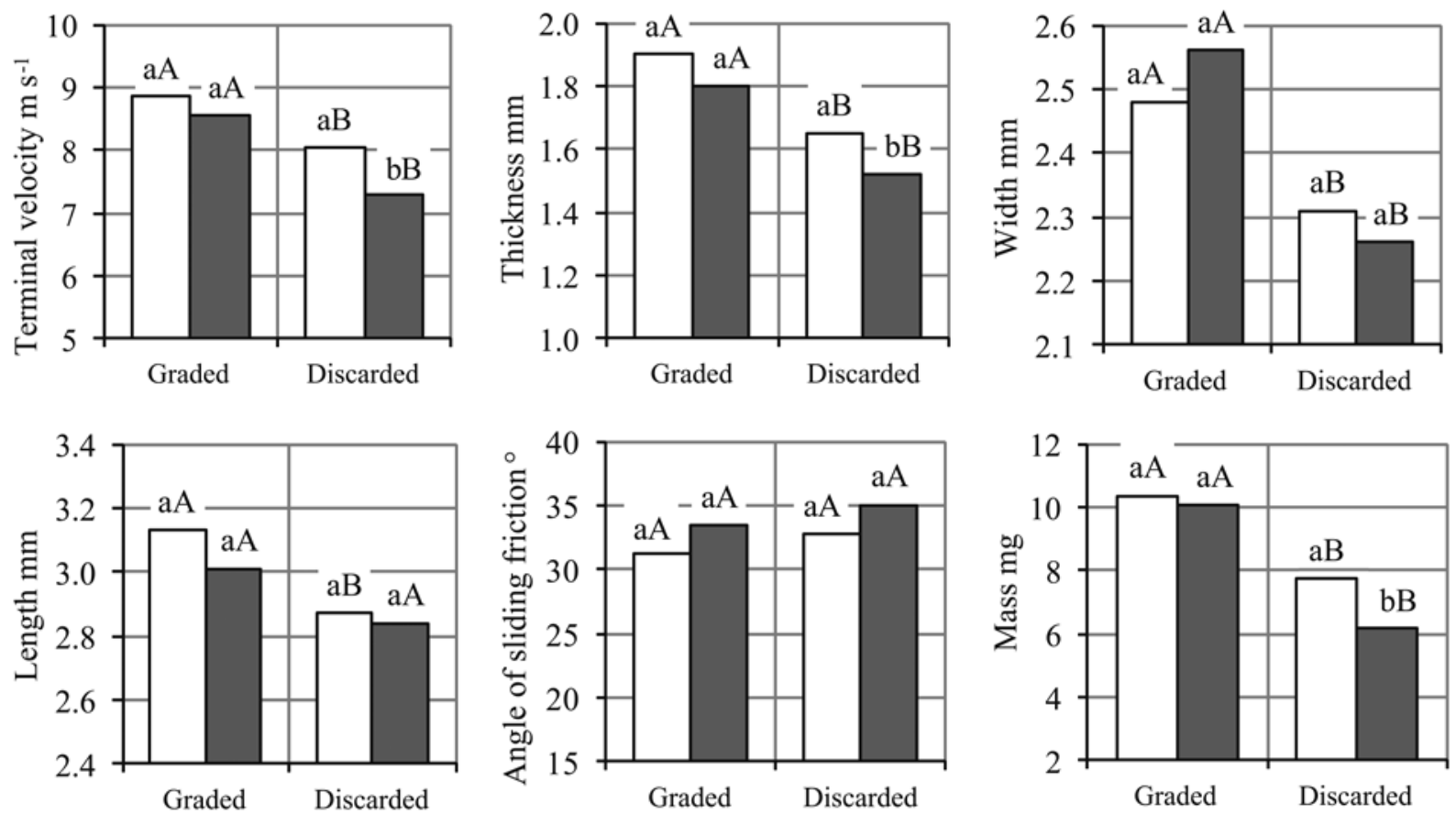

Note. $\square-$ germinated, - - non-germinated; a, b - different letters denote significant differences between germinated and nongerminated seeds; A, B - different letters denote significant differences between graded and discarded seeds.

Figure 3. Physical attributes of germinated and non-germinated cultivated radish seeds from the graded and discarded fractions

simple cleaning machines can be used interchangeably with no negative effect on separation efficiency. Strong relationships between seed attributed are desirable because they facilitate the design of processes and operations related to seed sowing, harvesting, storage and processing (Altuntas, Demirtola, 2007; Kabas et al., 2007; Riyahi et al., 2011; Sologubik et al., 2013), and enable simplification of the mathematical description of the above models. Interestingly, a significant correlation was also observed between the angle of external friction and the remaining parameters of cultivated radish seeds. The angle of external friction decreased with an increase in seed dimensions and mass. The parameter that was least correlated with the remaining traits was the germination rate index. This is undesirable, because in the sorting process seeds cannot be separated based on their germination rates which could contribute to greater germination uniformity. The germination rate index was not significantly correlated with the remaining parameters of graded seeds, but it was significantly correlated with the terminal velocity and mass of discarded seeds. This implies that only discarded seeds could be sorted out to ensure uniform germination. Heavier seeds of that fraction germinate earlier, which is consistent with the results reported by Mut and Akay (2010), Nik et al. (2011), Amin and Brinis (2013) for cereal seeds, and by Orzeszko-Rywka et al. (2013) for Festulolium seeds. Such a correlation was not found in common bean seeds (Ogutu et al., 2012).

Terminal velocity was adopted as the separation trait of cultivated radish seeds due to the highest value of the morphological index of seed separation (Fig. 1)

Table 2. Pearsons coefficients of correlation between selected parameters of cultivated radish seeds

\begin{tabular}{|c|c|c|c|c|c|c|c|}
\hline $\begin{array}{c}\text { Seed } \\
\text { fraction }\end{array}$ & Physical parameter & $T$ & $W$ & $L$ & $\gamma$ & $m$ & $W_{g}$ \\
\hline \multirow{6}{*}{$\begin{array}{c}\text { Graded } \\
\text { seeds }\end{array}$} & terminal velocity $(v)$ & 0.658 & 0.532 & 0.581 & -0.416 & 0.714 & 0.126 \\
\hline & thickness $(T)$ & & 0.418 & 0.485 & -0.593 & 0.702 & 0.095 \\
\hline & width $(W)$ & & & 0.738 & -0.243 & 0.847 & -0.087 \\
\hline & length $(L)$ & & & & -0.225 & 0.848 & 0.067 \\
\hline & angle of sliding friction $(\gamma)$ & & & & & -0.361 & -0.104 \\
\hline & mass $(m)$ & & & & & & -0.002 \\
\hline \multirow{6}{*}{$\begin{array}{c}\text { Discarded } \\
\text { seeds }\end{array}$} & terminal velocity $(v)$ & 0.808 & 0.457 & 0.300 & -0.373 & 0.776 & 0.307 \\
\hline & thickness $(T)$ & & 0.483 & 0.417 & -0.458 & 0.792 & 0.167 \\
\hline & width $(W)$ & & & 0.763 & -0.255 & 0.794 & 0.059 \\
\hline & length $(L)$ & & & & -0.234 & 0.739 & 0.046 \\
\hline & angle of sliding friction $(\gamma)$ & & & & & -0.344 & -0.138 \\
\hline & mass $(m)$ & & & & & & 0.244 \\
\hline
\end{tabular}

Note. Values in bold indicate that the correlation is significant at $p=0.05 ; W_{g}-$ germination rate index. 


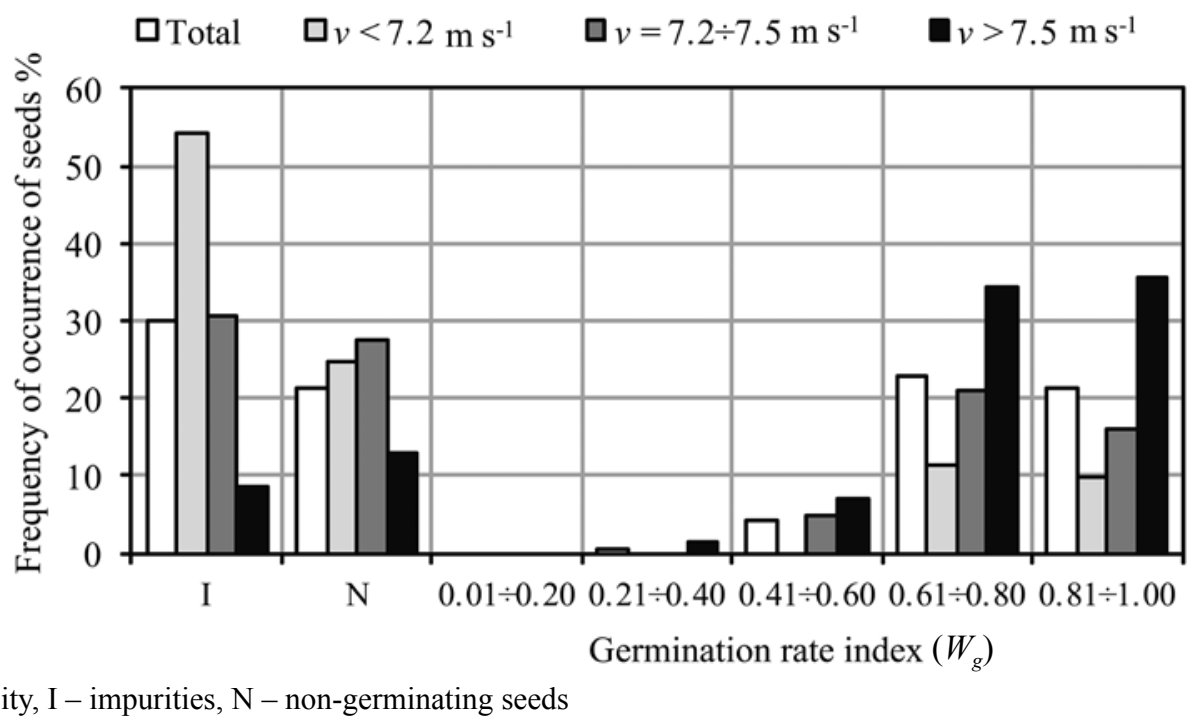

$v$ - terminal velocity, I - impurities, $\mathrm{N}$ - non-germinating seeds

Figure 4. Histogram of the germination rate index $\left(W_{g}\right)$ of discarded cultivated radish seeds

and significant correlations with the germination rate index (Table 2). The structure of the germination rate index before and after the separation of the seed mixture into three fractions (with nearly identical quantitative proportions) relative to terminal velocity is presented in Figure 4. A significant increase in the share of impurities was noted in fraction $\mathrm{I}\left(v<7.2 \mathrm{~m} \mathrm{~s}^{-1}\right)$, which implies that fraction I seeds should not be redirected to the graded product due to the risk of contamination. The graded mixture could be supplemented with fraction III $(v>7.5$ $\mathrm{m} \mathrm{s}^{-1}$ ) seeds with the highest terminal velocity. Fraction III is characterized by a significant increase in the share of fast germinating seeds $\left(W_{g}>0.6\right)$ and a lower share of impurities and non-germinating seeds in comparison with the discarded fraction.

The results of our analysis suggest that the graded seed mixture can be combined with the heavier fraction of discarded seeds separated in a vertical stream of air at the speed of $v=8 \mathrm{~m} \mathrm{~s}^{-1}$ to maintain minimum seed purity of $98 \%$. This procedure supports the recovery of approximately $37 \%$ of discarded seeds which contain $86 \%$ healthy germs. The separation process should consist of the following stages: cleaning of the threshed material with the use of a gravity separator (as in the Torseed Seed Production and Nursery Center in Torun, Poland), feeding the discard material into a pneumatic separator, and redirecting heavier seeds of that fraction to the graded batch. The final product is characterized by a germination energy $\left(V_{g}\right)$ of $72.4 \%$ and a germination capacity $\left(C_{g}\right)$ of $86.7 \%$.

\section{Conclusions}

1. Cultivated radish seeds from graded and discarded fractions separated on a gravity separator differed with regard to their terminal velocity, dimensions and mass. Graded seeds were characterized by higher average values of the analyzed parameters.

2. Germinated and non-germinated seeds from the graded fraction did not differ significantly, and discarded seeds differed significantly with regard to their terminal velocity, thickness and mass. The germination time of discarded cultivated radish seeds was significantly affected by terminal velocity and mass, whereas no significant correlations were observed in graded seeds.

3. The separation of cultivated radish seeds should take place in two stages with the use of a gravity separator and a pneumatic separator. Discards from the gravity separator should be fed into a channel with a vertical stream of air, and the seed fraction with the highest terminal velocity should be redirected to the graded batch. The above procedure supports the recovery of approximately $40 \%$ of discarded seeds. The resulting seed mixture is characterized by greater germination energy and capacity than the seed fraction graded on a gravity separator only.

Received 09052014 Accepted 04012015

\section{References}

Altuntas E., Demirtola H. 2007. Effect of moisture content on physical properties of some grain legume seeds. New Zealand Journal of Crop and Horticultural Science, 35 (4): $423-433$

http://dx.doi.org/10.1080/01140670709510210

Amin C., Brinis L. 2013. Effect of seed size on germination and establishment of vigorous seedlings in durum wheat (Triticum durum Desf.). Advances in Environmental Biology, 7 (1): 77-81

Andreoli C., Khan A. A. 2000. Integration of physiological, chemical and biological seed treatments to improve stand establishment and yield of vegetables. Acta Horticulturae, 533: $31-38$

Blažević I., Mastelić J. 2009. Glucosinolate degradation products and other bound and free volatiles in the leaves and roots of radish (Raphanus sativus L.). Food Chemistry, 113 (1): 96-102 http://dx.doi.org/10.1016/j.foodchem.2008.07.029

Çetin M., Şimşek E., Akbaş T., Özarslan C. 2010. Physical properties of radish (Raphanus sativus L.) seed as a function of moisture content. The Philippine Agricultural Scientist, 93 (3): 291-298

Domoradzki M., Korpal W. 2009. Germination analysis for coated radish seeds, carried out using four selected bed types. Inżynieria Rolnicza, 2 (111): 27-33 (in Polish)

Haq ul Z., Jamil Y., Irum S., Randhawa M. A., Iqbal M., Amin N. 2012. Enhancement in germination, seedling growth and yield of radish (Raphanus sativus) using seed pre-sowing magnetic field treatment. Polish Journal of Environmental Studies, 21 (2): 369-374 
Hojjat S. S. 2011. Effects of size on germination and seedling growth of some lentil genotypes (Lens culinaris Medik.). International Journal of Agriculture and Crop Sciences, 3 (1): $1-5$

ISTA 2014. International rules for seed testing. Zurich, Switzerland

Jamil Y., Haq ul Z., Iqbal M., Perveen T., Amin N. 2012. Enhancement in growth and yield of mushroom using magnetic field treatment. International Agrophysics, 26 (4): $375-380$ http://dx.doi.org/10.2478/v10247-012-0052-4

Kabas O., Yilmaz E., Ozmerzi A., Akinci I. 2007. Some physical and nutritional properties of cowpea seed (Vigna simensis L.). Journal of Food Engineering. 79 (4): 1405-1409 http://dx.doi.org/10.1016/j.jfoodeng.2006.04.022

Kaliniewicz Z., Grabowski A., Liszewski A., Fura S. 2011. Analysis of correlations between selected physical attributes of Scots pine seeds. Technical Sciences, 14 (1): $13-22$

Kang Y., Wan S. 2005. Effect of soil water potential on radish (Raphanus sativus L.) growth and water use under drip irrigation. Scientia Horticulturae. 106 (3): 275-292 http://dx.doi.org/10.1016/j.scienta.2005.03.012

Krawiec M., Dziwulska-Hunek A., Kornarzyński K., Palonka S. 2012. Effect of selected physical factors on radish (Raphanus sativus L.) seeds germination. Acta Agrophysica, 19 (4): 737-748 (in Polish)

Lynikiene S., Pozeliene A., Rutkauskas G. 2006. Influence of corona discharge field on seed viability and dynamics of germination. International Agrophysics, 20 (3): 195-200

Maroufi K., Farahani H. A. 2011. Increasing of germination by hydropriming method in radish (Raphanus sativus L.). Advances in Environmental Biology, 5 (10): 3440-3443

Martinez-Villaluenga C., Penas E., Ciska E., Piskula M. K., Kozlowska H., Vidal-Valverde C., Frias J. 2010. Time dependence of bioactive compounds and antioxidant capacity during germination of different cultivars of broccoli and radish seed. Food Chemistry, 120 (3): 710-716 http://dx.doi.org/10.1016/j.foodchem.2009.10.067
Muszyński S., Gładyszewska B. 2008. Representation of He$\mathrm{Ne}$ laser irradiation effect on radish seeds with selected germination indices. International Agrophysics, 22 (2): $151-157$

Mut Z., Akay H. 2010. Effect of seed size and drought stress on germination and seedling growth of naked oat (Avena sativa L.). Bulgarian Journal of Agricultural Science, 16 (4): 459-467

Nik M. M., Babaeian M., Tavassoli A. 2011. Effect of seed size and genotype on germination characteristic and seed nutrient content of wheat. Scientific Research and Essays, 6 (9): 2019-2025

Ogutu M. O., Muasya R., Ouma G. 2012. Effects of cropping system, planting location and inorganic nitrogen on quality of bean seed in Western Kenya. Advanced Research Journal of Agricultural Science, 1 (9): 261-274

Orzeszko-Rywka A., Rochalska M., Podlaski S., Grzywacz P. 2013. Seed separation as ecological method of seed quality improvement of Festulolium (Festulolium braunii). Journal of Research and Applications in Agricultural Engineering, 58 (4): 86-90 (in Polish)

Pérez Gutiérrez R. M., Perez R. L. 2004. Raphanus sativus (radish): their chemistry and biology. The Scientific World Journal, 4: 811-837 http://dx.doi.org/10.1100/tsw.2004.131

Riyahi R., Rafiee S., Dalvand M. J., Keyhani A. 2011. Some physical characteristics of pomegranate, seeds and arios. Journal of Agricultural Technology, 7 (6): 1523-1537

Sologubik C. A., Campañone L. A., Pagano A. M., Gely M. C. 2013. Effect of moisture content on some physical properties of barley. Industrial Crops and Products, 43: $762-767$

http://dx.doi.org/10.1016/j.indcrop.2012.08.019

Załęski A. 1995. Management of coniferous forest trees and shrubs for seed production. Warszawa, Poland (in Polish)

ISSN 1392-3196 / e-ISSN 2335-8947

Zemdirbyste-Agriculture, vol. 102, No. 2 (2015), p. 217-222

DOI $10.13080 / \mathrm{z}-\mathrm{a} .2015 .102 .028$

\title{
Ridikų sèklų fizikinių savybių ir daigumo sąsajos
}

\author{
Z. Kaliniewicz, K. Jadwisieńczak, P. Markowski, D. Choszcz, E. Kolankowska \\ Varmijos ir Mozūrų universitetas, Lenkija
}

\section{Santrauka}

Siekiant padidinti valgomojo ridiko (Raphanus sativus L.) sèklų išeigą/kokybę, tyrimo tikslas buvo nustatyti koreliacijas tarp sėklų aerodinaminių, trinties, morfologinių bei masės rodiklių ir daigumo. Šios savybės įvertintos rūšiuotose ir atmestose sèklose, priemaišas pašalinus sunkio jègos skirtuvu.

Sèklų daigumas buvo nustatomas kas 12 val. ir apskaičiuotas sèklų dygimo greičio indeksas. Rūšiuotos nesudygusios ir sudygusios sėklos esmingai skyrèsi tik pagal morfologiją - sèklų pločio ir ilgio santykị. Palyginus su nesudygusiomis sẻklomis, atmestos sudygusios sèklos pasižymėjo didesniu pločiu $(\sim 9 \%)$, mase $(\sim 26 \%)$, lyginamaja mase $(\sim 20 \%)$ ir tankiu $(\sim 10 \%)$, atmestoms sudygusioms sèkloms išpūsti reikejjo didesnio išpučiamo oro ribinio greičio $(\sim 10 \%)$. Atmestų sẻklų dygimo trukmė koreliavo su jų mase bei tankiu ir išpučiamo oro ribiniu greičiu. Taigi, ridikų sẻklos turètų būti rūšiuojamos pirmiausia sunkio jègos skirtuvu, vèliau oro pūstuvu. Vertikali $8 \mathrm{~m} \mathrm{~s}^{-1}$ greičio oro srovè atskyrè apie $37 \%$ atmestų sėklų, kurių $86 \%$ buvo su sveikais gemalais. Dviem prietaisais atskirtų sẻklų mišinys buvo daigesnis ir didesnès dygimo energijos, palyginus su sẻklomis, rūšiuotomis tik sunkio jègos skirtuvu.

Reikšminiai žodžiai: dygimas, fizikinès savybès, ridikų sèklos. 